Катарина Митрићевић-Штепанек

Универзитет у Београду

Филолошки факултет

Катедра за славистику

k.mitricevic@fil.bg.ac.rs
УДК 811.162.3'367.625: 811.163.41'367.625 https://doi.org/10.18485/slavistika.2018.22.2.9 оригинални научни рад примљено 04.03.2018. прихваћено за штампу 04.10.2018.

\title{
ПРОУЧАВАЬЕ ГЛАГОЛСКИХ ПРЕФИКСА У ЧЕШКОМ И СРПСКОМ ЈЕЗИКУ СА ОСВРТОМ НА ДРУГЕ СЛОВЕНСКЕ ЈЕЗИКЕ
}

\footnotetext{
У раду се скреће пажња на глаголске префиксе као предмет конфронтативног истраживања у српском и чешком језику са краћим освртом на проучавања у српском и другим словенским језицима. Даје се преглед радова који су посвећени овим језичким јединицама и истиче се њихов допринос описима словенских језика појединачно и у целини.
}

Kључне речи: глаголски префикси, глаголске префиксалне изведенице, конфронтативна анализа, српски језик, чешки језик, словенски језици.

The paper focuses on verbal prefixes as the subject of contrastive research in the Serbian and Czech languages and provides a brief overview of research on this topic in Serbian and other Slavonic languages. The study gives a review of works dedicated to these language units and emphasizes their contribution in describing Slavonic languages individually and as a whole.

Keywords: verbal prefixes, verbal derivatives, contrastive analysis, Serbian language, Czech language, Slavonic languages.

Глаголски префикси узимани су за предмет конфронтативних дијахронијских и синхронијских истраживања у српском и другим словенским језицима и проучавани су у целини или појединачно, анализама су обухваћене њихова формална и семантичка страна, као и њихова граматичка функција перфективизације и лексичка функција семантичке модификације, а приказивано је стање у два или више језика или у словенским језицима уопште.

На пример, Ана Марић (Marićová 2008) бавила се глаголским префиксима у словачком и српском језику у обимном истраживању у ком анализира формалну и семантичку страну датих јединица у оквиру три главне семе: локализованости, темпоралности и модалитета глаголске радње, утврђујући знатно формално, али и значењско подударање које је највеће у оквиру просторних значења, а најмање у оквиру модалитета радње, посвећујући посебну пажњу неподударањима у ова два језика. ${ }^{1}$ У бројним радовима, од којих дајемо само избор, бавила се такође односом префикса и предлога (Marić 1996; Марић 2003), паралелама између глаголских са једне и именских, придевских и прилошких префикса са друге стране (Марић 2005), семантиком рефлексивних глагола (Марић 2006), дистрибутивних глагола (Марић 1988), префиксацијом двовидских глагола (Марић 2004), чисто видским префиксима (Марић 2002), комбинацијама префикса у двопрефиксалним изведеницама (Marićová 2008) и др.

Вера Митриновић (Митриновић 1986) је за предмет своје обимне дијахронијске и синхронијске конфронтативне анализе узела префикс prze- у пољском

${ }^{1}$ Ради се о докторској дисертацији (Marićová 2002) објављеној потом као монографија. 
и пре- и про- у српском језику, пратећи њихов развој од индоевропског корена, преко њихових прасловенских облика, до данашњих рефлекса у ова два језика, утврђујући њихова значења, од просторних, временских, преко семантике велике и мале количине и других значења, не занемарујући ни функцију перфективизације. У другим радовима ауторка је анализирала семантички садржај глагола кретања са префиксима до- и при- у руском језику и њихових еквивалената у пољском и српском, а бавила се и аспекатском акомодацијом глагола страног порекла у пољском и српском језику и закључила да постоји знатно већи број двовидских глагола у српском језику него у пољском и, сходно томе, да је у њему мање изражена употреба механизма перфективизације додавањем префикса (Mitrinović 2012).

Више истраживача бавило се префиксима у руском и српском језику. Значењима префикса за- бавила се Десанка Стефановић (Стефановић 1983), полазећи од основног, просторног значења „заузимати положај иза предмета“, преко семантике залажења у унутрашњост, прекривања, заклањања објекта, стицања, присвајања, до значења почетка радње као најпродуктивнијег, значења прекорачења норме у трајању радње, те значења претераности. Префиксацију глагола кретања у руском и српском проучавала је Јелка Матијашевић (Матијашевић 1985), наглашавајући да се у оба језика приликом њихове творбе активира скоро сав потенцијал префикса, као и да се код префиксалних глагола испољава висок степен сличности. Ауторка је такође посветила пажњу префиксацији двовидских глагола у руском и српском, која обухвата како домаће тако и глаголе страног порекла у ова два језика (Матијашевић 2000). Изведенице са двоструким префиксом пона- анализирао је Александар Терзић (Терзић 1997) и закључио да глаголи са овом префиксалном групом у српском и руском језику чувају творбено значење префиксалних глагола који их генеришу, на које се творбено значење изведених структура са префиксом по- наноси као додатна специфична нијанса, а прожимањем значења ова два префикса, као и основе, настају подтипови ових изведених глагола.

Улога префиксалних изведеница проучавана је и у оквиру категорије акционалности. Овом категоријом у српском и украјинском језику бавила се Људмила Поповић (Поповић 2010) која је на основу когнитивног метода и теорије семантичких локализација издвојила три осе полидимензионалног простора које су различито профилисане у базном домену концептуализације аспектуалних карактеристика глагола, а ауторка се овом проблематиком бавила обухвативши такође све словенске језике (Поповић 2007). Бавила се и концептуализацијом просторних односа на примеру глагола кретања у српском и украјинском језику закључивши да је репертоар префикса који изражавају просторно кретање разноврснији у украјинском језику (Поповић 2009), те значењем проспективности, где на примерима из различитих словенских језика показује да је ова категорија организована као функционално-семантичко поље у чијем центру су глаголи кретања, као и прилози и прилошке конструкције који са одговарајућим предикатима реализују ово значење (Поповић 2008). Акционалне модификације у украјинском и српском језику истраживала је у обимној анализи Милена Ивановић (Ивановић 2016) обухвативши како синтетичка (творбена), тако и аналитичка средства изражавања ове категорије у оквиру које је обрадила више 
типова акционалних модификација ситуације, а поређењем функционисања ове категорије у два језика утврдила да постоји знатна сличност у асортиману акционалних значења и средствима њиховог изражавања, а са друге стране да су у украјинском језику акционалне класе глагола као синтетичка средства знатно продуктивније, док српски језик не користи у пуној мери своје творбене потенцијале и предност даје аналитичким средствима. ${ }^{2}$ Ауторка се такође бавила овом проблематиком у оквиру засебних радова у којима анализира сличности и разлике у творбеним средствима и семантици нпр. конструктивних почетних глагола, финалних глагола, те у оквиру делимитативних модификација ситуација (Ивановић 2008, 2009, 2012, 2014).

Бранко Тошовић (Тошовић 2009) истраживао је у својој монографији начине глаголске радње у српском, хрватском и бошњачком језику. Аутор их прецизира и класификује, и то према модификацији значења која се испољава у облику промене степена, норме, квантитета и секвентности, дајући бројне примере у српском, хрватском и бошњачком, али и руском језику.

Наше истраживање засновано је на творбено-семантичкој анализи глаголских префикса који изражавају семантичку црту квантитета, прецизније велике и мале количине радње, у чешком језику и њихових еквивалената у српском језику са циљем да се открију међујезичке сличности и разлике у ова два језика на пољу функционисања глаголске префиксације и глаголских изведеница у систему чешког и српског језика. ${ }^{3}$

На првом месту издвојили смо, на основу претходне литературе о датим језичким јединицама и лексикографске грађе, глаголске префиксе који у чешком језику изражавају семантику квантитета, а потом анализирали њихова појединачна значења и утврдили еквиваленте у српском језику. ${ }^{4}$ Утврдили смо да сему квантитета изражавају глаголски префикси у оба језика и да се она испољава на разне начине и кроз различита значења и значењске нијансе. ${ }^{5}$ У чешком језику деривати нпр. изражавају да се радња врши до миле воље, до задовољења (povykládat si, nasmát se, proběhnout se, vyspat se, zatančit si), преко жељене мере и воље за радњу (nakopat se), или се врши у претераној и надстандардној мери (přpracovat se, nadcenit, přecenit), или њено вршење

${ }^{2}$ У питањује докторска дисертација (Ивановић 2013) касније објављена као монографија.

${ }^{3}$ Ради се о докторској дисертацији (Митрићевић-Штепанек 2015). Проблематиком глаголских префикса и њихових деривата бавили смо се и у оквиру појединачних радова (Митрићевић-Штепанек 2012, 2015, 2016).

4 Грађа је ексцерпирана из једнојезичних речника чешког и српског језика и двојезичног чешко-српског речника које наводимо у одељку Извори, док смо као главни извор за утврђивање формалних средстава која учествују у грађењу префиксалних изведеница, те њихове семантике користили граматике и приручнике чешког и српског језика, као и бројне појединачне радове о наведеној проблематици. То су између осталих Príruční mluvnice češtiny (Karlík et al 1996), Mluvnice češtiny I (Dokulil 1986), Novočeské tvoření slov (Šmilauer 1971), Slovesné predpony (Uher 1987), Čeština - ̌reč a jazyk (Čechová et al. 2000), Творба речu у савременом српском језику I (Клајн 2002), Савремени српскохрватски језик I (Стевановић 1964), Историја српскохрватског језика II (Белић 1962), Савремени српскохрватски књижевни језик II (Белић 1949), Gramatika hrvatskog ili srpskog jezika (Maretić 1963).

${ }^{5}$ У формирању неких значења учествује поред префикса рефлексивна морфема, која је саставни део творбеног форманта — у чешком језику se, si а у српском језику $c e$.

Славистика XXII/2 (2018) 
доводи до уништења, исцрпљења, смрти (ubodat, upracovat se, unosit), или се ради о интензивном, детаљном вршењу радње (probádat, vychválit, sjezdit), или о њеном дугом трајању (prospat, vystát, zapovídat se) и друго. У српском језику семантика велике количине радње испољава се такође кроз различита значења, нпр. радња се врши до миле воље, до задовољења (поиграти се, наспавати се, проваљати се, испавати се), преко жељене мере и воље за радњу (начекати ce), до крајњих граница (изударати), или се врши у претераној мери (прејести ce, преценити), или се ради о интензивном, детаљном вршењу радње (измолити, простудирати, исхвалити), или о њеном дугом трајању (преспавати, уседети се, запричати се) итд. Код семантике мале количине радње у чешком језику радња се извршава у мањој мери, делимично (ojínit, poblednout, priškrtit), или испод уобичајене мере (podhodnotit), а често је одређена трајањем и дефинисана као почетна (nalomit), кратка (pohoupat, usmát se), или вршена до миле воље, до задовољења (pokochat se, schrupnout si, zacvičit si), а повезана је и са извршењем у простору (naklonit, nadnést, omýt). У српском језику квантитет је често повезан са дуративношћу, па је тако радња краткотрајна (полежати, причекати, провеселити се), или само на свом почетку (напући), или се ради о делимичној, непотпуној радњи (засећи, нагристи, назначити, пригушити), или је пак извршена испод нормалне мере (потиенити) и слабијим интензитетом (подгрејати) и друго.

На основу поређења формалне стране велику количину радње у чешком језику изражава 10 префикса (na-, nad-, po-, pro-, pre-, s-, u-, vy-, z- и za-), док у српском језику само 5 (за-, из-, нa-, пре- и $y$-), дакле упола мање средстава учествује у изражавању ове семантике. Што се тиче саме еквиваленције 6 , формална еквиваленција обухвата префиксе $n a-:$ на-, po- : no-, pro- : npo-, pře- : npeи za- : за-. Префикси $n a-$ и pře- имају формалне еквиваленте у српском језику у свим појединачним значењима (natrhat-начупати, načekat se - начекати ce, nazpívat se - напевати се; preplnit - nрепунити). Исто је и са префиксом po- који заправо изражава неспецификовану, тј. и велику и малу количину радње у зависности од контекста, али треба нагласити да се мера, тј. трајање радње у литератури о српском језику пре посматра као краће него као дуже (pohrát si - nоиграти ce). ${ }^{7}$ Префикс pro- такође има формалне еквиваленте у свим значењима (prostudovat - nростудиратu, propít - nponumu, proválet se - проваљати се), међутим, сматрамо да су у значењу „провести дуже време у одређеној радњи“ (prospat) фреквентније изведенице са префиксом пре(преспавати) у односу на оне са префиксом про- (проспавати).

Када говоримо о семантичкој еквиваленцији, префикс vy- има у српском језику два еквивалента, од којих из- у значењима: „извршење радње до крајњих граница“ (vychválit - исхвалити) и „извршење радње до задовољења потребе, доста“ (vyspat se - испавати ce), док је у значењу „провести дуже време у

${ }^{6} \mathrm{O}$ типовима еквиваленције вид. нап. 8 .

${ }^{7}$ У Речнику српскога језика (Вујанић et al. 2007) изведенице се дефинишу на следећи начин: поиграти се - провести неко време у игри; полежати - провести неко време лежећи; поспавати - мало одспавати. Као краће време вршења радње дефинишу ове префиксале И. Клајн (Клајн 2002: 266), М. Стевановић (Стевановић 1964: 460), Т. Маретић (Maretić 1963: 385). А. Белић каже да глаголи поиграти, поспавати, покуцати, потражити изражавају „вршење радње у малој мери“ (Белић 1949: 305). 
вршењу радње“ његов еквивалент префикс npe- (vystát - nрестајати). Глаголи с префиксима $s$ - / z- имају еквиваленте са префиксом про- у значењу „проласка кроз или поред већег броја објеката“" (scestovat - пропутовати). У значењу „трајања радње преко пожељне мере“ префикс $z a-$ има формални еквивалент у српском језику (zapovidat se - запричати се). За значење „вршења радње потпуно, по целој површини објекта“" еквивалент у српском језику је префикс y- (zašpinit - yпрљати). Семантику „вршења радње до миле воље“ заступа префикс no- (zacvičit si-nовежбати). Два префикса немају ни у једном значењу формалне еквиваленте: nad- и $u$-. Еквивалент префикса nad- је, као и за pře-, префикс пре- (nadcenit - преценити). За префикс $u$ - фигурирају еквиваленти са префиксима из- (ипоsit-износити) и пре- (umlátit-nремлатити), с тим што се у другом наведеном случају у значењу „радњом убити или исцрпсти објекат“ ради само о делимичним синонимима који морају најчешће бити допуњени неким елементима који прецизирају ту семантику (umlátit - премлатити на смрт, upovídat (se) - изморити (ce) причом). Најфреквентнији семантички еквивалент у српском језику представља префикс пре-.

Што се тиче мале количине радње, формална страна показује да је у чешком и српском језику приближан инвентар префикса који изражавају дату семантику, али опет у корист чешког језика (11:9), дакле у чешком (na-, nad-, o- и ob-, od-, po-, $p o d-$, pri-, s-, u- и za-) а у српском (за-, на-, o-, oб, по-, nод-, пре-, при- и про-). Формална еквиваленција обухвата префиксе $n a-$ : на- (nakousnout - нагристи), po- : no- (požertovat si-nомалити се), pod- : nод- (podcenit-nотценити), při- : при- (přitlumit - пригушити) и о-, ob- : o-, об- (ovlažit - овлажсити).

У оквиру семантичке еквиваленције префикс $o d$ - има за еквивалент префикс nро- (odeprat - nропрати). Значењу „краткотрајне радње“ префикса $s$ - одговара префикс про- (schrupnout si-npoдремати), а у значењу „делимичног захватања објекта по површини“" префикси о- и об- (sтосіt - оквасити). Код префикса $z a-$ у значењу делимичне радње фигурира као еквивалент префикс про- (zaschnout - просушити се), а код значења повезаног са темпоралношћу то је префикс по(zacvičit si-nовежбати). Префикс $u$ - у чешком језику нема у српском језику семантички истоветне еквиваленте у виду префиксала. У значењу „радњом нешто мало одвојити из целине“ као еквивалент може да послужи изведеница са префиксом од- у значењу сепаративности, али она мора бити допуњена неким елементом који прецизира малу количину радње (ulít - одлити мало чега), док је друга могућност употреба беспрефиксалног деминутивног глагола са суфиксом -ну- (uždibnout- uтрпнути). У значењу „извршења неке кратке мимичке или вербалне радње“ еквиваленти могу бити глаголи који имају семантику мање мере, али њихови префикси сами по себи не изражавају малу количину радње (usmát se-осмехнути се, насмешити се). Префикс про- је најфреквентнији у функцији семантичког еквивалента.

Други део истраживања посвећен је детаљној анализи два префикса, $n a$ и $u$-, који у чешком језику изражавају како велику тако и малу количину радње, јер смо на основу прелиминарних истраживања претпоставили (што се и потврдило) да на пољу функционисања глаголске префиксације и глаголских изведеница у систему чешког и српског језика префикс $n a-/ н a$ - илуструје међујезичку сличност, а префикс $u$-/y- међујезичку различитост између ова 
два језика. Прво смо у чешком језику маркирали глаголске префиксалне изведенице које изражавају семантику мале и велике количине радње и прецизирали њихов семантички садржај. Наиме, издвојили смо појединачна значења и значењске нијансе на основу њихове лексикографске дефиниције, утврдили степен продуктивности, синонимичне односе са другим изведеницама и односе међу семемама код полисемичних лексема, као и функционисање префиксала у контексту и у оквиру образовања одређених семантичких група и др. Затим смо исти поступак применили на грађи која обухвата еквиваленте у српском језику, а потом анализирали типове еквиваленције ${ }^{8}$ у утврдили смо формалне (на- и $y$-) и семантичке еквиваленте, прецизирали преводну семантизацију, дефинисали конвергентне и дивергентне односе, анализирали подударање лексикографских и контекстуалних еквивалената и понудили решења у виду различитих начина транспозиције узимајући у обзир комуникативну функцију целог исказа.

На основу наведене анализе извели смо одређене закључке. Као прво, префикс $n a-$ у чешком језику веома је продуктиван у изражавању семантичке црте велике количине радње, где највише изведеница има значење „радњом накупити, нагомилати“ (nasbirat), следи „много, често, дуго вршити/проживљавати радњу““ (načekat se) и најзад „вршити радњу до задовољења субјекта“ (nabažit se). Што се тиче семантике мале количине радње, префикс је продуктиван у значењу „делимично извршити радњу“ (nahlodat), док је у значењу „извршити радњу слабијим интензитетом“ (načeřit) слабо продуктиван, а „извршити кратку, тренутну радњу“" (nakouknout) чак непродуктиван, са свега 3 префиксала.

Што се тиче еквивалената у српском језику, префикс на- продуктиван је у изражавању семантичке црте велике количине радње (набрати; начистити се; наодмарати се), а пре свега у значењу кумулативности. Код свих анализираних значења преовлађује тип формалне еквиваленције чији је број већи од 50 \% од укупног броја еквивалената (nadojit - намусти; načistit se - начистити се; nahvízdat se - назвиждати се). Следе семантички еквиваленти заступљени изведеницама са неким другим префиксом (nafackovat-ишамарати, napáchat-nочинити много тога, našpinit - запрљљати већу количину чега), од којих је најбројнији и семантички најприближнији префикс из- у значењу „извршити радњу у довољној мери, у потпуности, до краја“, а на трећем месту функцију еквивалената имају беспрефиксални глаголи (nalichvařit - стећи лихварењем; nadychtit se - много и често жудети; narýpat se доста/до миле воље роварити).

Код изражавања мале количине радње префикс на- је продуктиван у значењу „делимично извршити радњу“ са 50 \% формалних еквивалената (napuknout -

${ }^{8}$ Типови еквиваленције у српском језику су: 1 . Формална еквиваленција - изведеница грађена истим префиксом, са истим или приближним значењем; 2. Семантичка еквиваленција - а. изведеница грађена другачијим префиксом, са истим или приближним значењем, евент. прецизираним додатним елементима (најчешће квантитативним); б. беспрефиксални глагол, евент. прецизиран додатним елементима (најчешће квантитативним); в. конструкције с неглаголским лексемама: конструкција с придевском изведеницом грађеном префиксом или суфиксом са истим или приближним значењем, евент. прецизираним додатним елементима (најчешће квантитативним); г. остали начини транспозиције (описна дефиниција, устаљени изрази, додавање и прерасподела елемената у контексту итд.). 
наnyћu), док су на другом месту поново изведенице са неким другим префиксом (nakasat - задићи, natužit - делимично уштиркати, napilovat - делимично отурпијати), од којих су најбројнији деривати са префиксом за- у истом значењу, и на трећем месту као еквиваленти функционишу беспрефиксални глаголи, обично изведени суфиксом -ну- који често означавају кратку, тренутну радњу, (naklepnout - чукнути), од чега овај трећи тип чини тек неколико лексема. Значење „извршити радњу слабијим интензитетом“ представљено је са свега два префиксала (нажутети, нагрејати), а по питању еквиваленције на првом месту по бројности су изведенице са неким другим префиксом (narudnout - мало поирвенети, заирвенети се), док су на другом месту формални еквиваленти (nahřát - нагрејати), следе затим беспрефиксални глаголи (nakopnout - ритнути), а као још једна могућност изражавања овог значења појављују се у малом броју и конструкције с придевским изведеницама са суфиксом -acm који уноси у мотивну реч деминутивну нијансу (naryznout - постати риђаст). У значењу „извршити кратку, тренутну радњу“ префикс на- такође је непродуктиван и семантика је представљена само једном изведеницом као формалним еквивалентом (nakouknout - навирити).

Префикс $u$ - у чешком језику неједнако је заступљен у изражавању семантичке црте велике количине радње. Наиме, веома је продуктиван код значења „вршити радњу до исцрпљења или смрти субјекта/објекта“"(umučit, uběhat se), док је слабо продуктиван у остала два значења: „уништити или оштетити објекат сталном или честом радњом“ (uprat) и „постићи резултат или жељени циљ интензивним вршењем радње“" (umluvit). У изражавању мале количине радње префикс $u$ - је продуктиван у значењу радњом „одвојити/одстранити мању количину из целине“ (udrolit), док су остала два значења, „извршити кратку (вербалну или мимичку) радњу“ (ušpulit se) и „извршити мањи покрет у страну или уназад“ (uklonit) заступљена са мање од по 10 изведеница.

На основу анализе еквивалената закључили смо да у српском језику префикс $y$ - не изражава појединачна значења утврђена у чешком језику у оквиру велике и мале количине радње јер смо пронашли један једини префиксал (умолити), дакле и једини формални еквивалент, са значењем „постићи резултат или жељени циљ интензивним вршењем радње“. Уосталом, префикс $y$ - изражава семантику велике, односно мале количине радње само у значењима радње продужене преко мере (уседети се, улежати се, устајати се, усмрдети се) и потпуног обухватања глаголском радњом (улепити, умазати, упрљати) која су непродуктивна. ${ }^{9}$ Сходно томе, у недостатку еквивалената, мора се прибећи неким другим начинима транспозиције као што су опис значења или употреба беспрефискалног глагола. У оквиру велике количине радње значење „вршити радњу до исцрпљења или смрти субјекта/објекта“" транспонује се у српски језик на првом месту описом значења који садржи елементе који прецизирају радњу која доводи до великог замора или смрти (ukamenovat - убити каменујући, užvanit se-исирпити се, пропасти брбљајући, ulechtat - уморити голицањем, utančit se - nосустати плешући, ukřičet se - nyћu вичући), док се на другом месту налазе изведенице грађене неким другим префиксом (utrápit- измучити, umačkat - nригњечuти, uhřát se - nрегрејати се). Наведено значење могуће је

${ }^{9}$ Примере и дефиниције значења наводи И. Клајн (Клајн 2002: 283).

Славистика XXII/2 (2018) 
утврдити као благу семантичку нијансу код неколицине глагола са префиксом $y$ (утући, умлатити) у поређењу са чисто видским парњацима (утући : истући, умлатити : измлатити), али се они не наводе у датом значењу у литератури. Код семантике „уништити или оштетити објекат сталном или честом радњом“ најбројније су у функцији еквивалената изведенице са неким другим префиксом (unosit - износити, похабати, ukopat - оштетити ударцима ноге), а затим следи опис значења (uběhat si - ynропастити од ходања, трчкања, utleskat si одвалити руке, дланове пљескајући). За значење „постићи резултат или жељени циљ интензивним вршењем радње“, које има један формални еквивалент (uprosit - умолити), најфреквентнији еквиваленти су изведенице са неким другим префиксом (umluvit - наговорити), а затим следи опис значења (užadonit - намолити, наговорити мољакајући, ulichotit - ласкањем, додворавањем придобити). У оквиру мале количине радње за сва значења најбројније еквиваленте представљају изведенице са неким другим префиксом (usypat одасути мало чега, usát - исисати мало чега, udrobit - прозборити пар речи, uсоиvnout - устукнути, узмакнути), док се у веома малом броју појављује опис значења (ubrousit - делимично отурпијати, истурпијати) и беспрефиксални глаголи, и то само код семантике „радњом одвојити/одстранити мању количину из целине“" (uždibnout - штрпнути), опет најчешће изведени већ поменутим суфиксом -ну-.

За сва значења у оквиру велике и мале количине радње треба напоменути да се начини транспозиције често комбинују, као и да се по потреби посеже за одређеним додатним елементима, најчешће квантитативним, како би се у недостатку формалног еквивалента што прецизније изразила дата семантика.

Можемо закључити да глаголски префикси представљају интересантно полазиште у конфронтативним истраживањима словенских језика, којих је до данас, са различитим закључцима и резултатима, било доста, као и да њихов богат семантички потенцијал нуди бројне могућности за даља проучавања. Сва та истраживања доприносе описима ових језика конфронтативно и појединачно и употпуњују слику о систему глаголских префикса и њихових деривата у словенским језицима у целини.

\section{Цитирана литература}

Белић, Александар. Савремени српскохрватски књижевни језик: наука о грађењу речи. Део 2. Београд: Научна књига, 1949.

Белић, Александар. Историја српскохрватског језика: речи са конјугацијом. Књ. 2. Св. 1. Београд: Научна књига, 1962.

Ивановић, Милена. „Функционисање конструктивних почетних глагола у ужем смислу у украјинском и српском језику“. Славистика XII, 2008: 258-268.

Ивановић, Милена. „Функционисање конструктивних почетних глагола у ширем смислу у украјинском и српском језику“. Славистика XIII, 2009: 187-196.

Ивановић, Милена. „Акционалне класе финалних глагола у украјинском и српском језику“. Славистика XVI, 2012: 206-214.

Ивановић, Милена. Изражавање акционалности у украјинском и српском језику. Докторска дисертација. Београд: Филолошки факултет, 2013. 
Ивановић, Милена. „Акционалне делимитативне модификације у српском и украјинском језику“. Славистика XVIII, 2014: 242-251.

Ивановић, Милена. Акционалност - семантика и форма: у савременом украјинском и српском језику. Београд: Филолошки факултет, 2016.

Клајн, Иван. Творба речи у савременом српском језику. Слагање и префиксација. Део 1. Београд: Завод за уџбенике и наставна средства, 2002.

Марић, Ана. „Вокализирани облици глаголских префикса у словачком и српском језику у односу на предлоге и њихова најчешћа значења“. Славистика VII, 2003: 117-124.

Марић, Ана. „Паралеле између глаголских и именских префикса у словачком и српском језику“. Славистика IX, 2005: 177-184.

Марић, Ана. „Повратни глаголи у словачком и српском језику“. Славистика X, 2006: 180-186.

Марић, Ана. „Дистрибутивни глаголи у словачком и српскохрватском језику“. Живи језици XXX, 1-4, 1988: 41-45.

Марић, Ана. „Глаголски вид и начини глаголске радње у словачком и српском језику“. Славистика VIII, 2004: 148-153.

Марић, Ана. „Перфективност радње изражена префиксалним глаголима у словачком и српском“. Славистика VI, 2002: 235-241.

Матијашевић, Јелка. „О природи префикса код глагола кретања у руском и српскохрватском језику“. МСЦ Научни састанак слависта у Вукове дане 14, 2, 1985: 139-147.

Матијашевић, Јелка. „Префиксација и двовидност глагола“. Јужнословенски филолог 56, 1-2, 2000: 655-663.

Митрићевић-Штепанек, Катарина. „Префиксација као процес интеграције глаголских позајмљеница у чешком и српском језику“, Opera Slavica XXII, 2, 2012: 11-22.

Митрићевић-Штепанек, Катарина. „Семантика 'уништења/оштећења објекта' глагола са префиксом у- у чешком језику и њихови еквиваленти у српском језику“. Славистика XIX, 2015: 162-170.

Митрићевић-Штепанек, Катарина. Глаголски префикси у функцији изражавања количине радње у чешком и српском језику. Докторска дисертација. Београд: Филолошки факултет, 2015.

Митрићевић-Штепанек, Катарина. „Глаголски префикс у- са значењем 'извршити кратку вербалну или мимичку радњу' у чешком језику и његови еквиваленти у српском језику“. Славистика XX, 2016: 687-694.

Митрићевић-Штепанек, Катарина. „Проучавање глаголских префиксалних деривата у српском језику у поређењу са чешким“. [In:] V. Štěpánek, J. Mitáček (eds.) Studia Balkanica Bohemo-Slovaca VII. Brno: Matice moravská, 2017, 615-629.

Поповић, Људмила. Језичка слика стварности: когнитивни аспект контрастивне анализе. Београд: Филолошки факултет, 2008.

Поповић, Људмила. „Когнитивни приступ опису категоризације акционалности у словенским језицима“. МСЦ Научни састанак слависта у Вукове дане 36, 1, 2007: 37-53.

Поповић, Људмила. „Посматрач и његова улога у концептуализацији просторних односа у језику: на примеру контрастивне анализе глагола кретања у српском и украјинском језику“. Славистика XIII, 2009: 399-410.

Славистика XXII/2 (2018) 
Поповић, Људмила. „Изражавање аспектуалног значења проспективности у словенским језицима“. Зборник Матице српске за славистику 73, 2008: 297-314.

Стевановић, Михаило. Савремени српскохрватски језик: граматички системи и књижевнојезичка норма. Део 1. Београд: Научно дело, 1964.

Стефановић, Десанка. „Значење префикса за у руском и српскохрватском језику“, Живи језици XXV, 1-4, 1983: 5-18.

Терзић, Александар. „Структурно-семантичке карактеристике глагола са префиксалном групом пона- у руском и српском језику“. МСЦ Научни састанак слависта у Вукове дане 26, 2, 1997: 309-330.

Тошович, Бранко. Способы глагоьного действия в сербском, хорватском и бошняцком языках. Katowice: Wydawnictwo Uniwersytetu Śląskiego. 2009.

Čechová, Marie et al. Čeština - řeč a jazyk. Praha: ISV nakladatelství, 2000.

Dokulil, Miloš, Karel Horálek, Jiřina Hůrková (eds.) Mluvnice češtiny I: fonetika, fonologie, morfonologie a morfemika, tvoření slov, Praha: Academia, 1986.

Karlík, Petr, Marek Nekula, Zdenka Rusínová (eds.) Příruční mluvnice češtiny. Praha: Nakladatelství Lidové noviny, 1996.

Maretić, Toma. Gramatika hrvatskog ili srpskog jezika. Zagreb: Matica hrvatska, 1963.

Marićová, Anna. „Kombinácia slovesných predpôn v slovenčine a srbčine“. Slovakistický zborník 3, 2008: 47-57.

Marićová, Anna. Systém slovesných predpôn v slovenčine a srbčine. Doktorská dizertácia. Novi Sad: Filozofski fakultet, 2002.

Marićová, Anna. Slovesné predpony v slovenčine a srbčine. Bačský Petrovec: Slovenské vydavatelské centrum, 2008.

Marić, Ana. „Odnos prefiksa i predloga u okviru lokalizacije radnje“. Kontrastivna jezička istraživanja, 1996, 186-192.

Mitrinović, Vera. Poljski glagolski prefiks prze- i njegovi srpskohrvatski ekvivalenti pre- i pro-, konfrontativna studija. Doktorska disertacija. Beograd: Filološki fakultet, 1986.

Mitrinović, Vera. Południe - Północ: Serbsko-polskie paralele językowe. Poznań: Wydawnictwo Naukowe, 2012.

Šmilauer, Vladimír. Novočeské tvoření slov. Praha: Státní pedagogické nakladatelství, 1971.

Uher, František. Slovesné předpony. Brno: Univerzita J. E. Purkyně, 1987.

\section{Извори}

Андрић, Драгослав. Речник жаргона. Београд: БИГЗ, 1976.

Вујанић, Милица et al. Речник српскога језика. Нови Сад: Матица српска, 2007.

Качаник, Емилија et al. Чешко-српски речник I, II. Београд: САНУ, 2001.

Копривица, Верица. Чешко-српски и српско-чешки речник. Београд: Агенција Матић, 2008.

Пешикан, Митар et al. (eds.) Речник српскохрватског књижевног и народног језика XIII-XIV. Београд: САНУ, 1988-1989.

Стевановић, Михајло et al. (eds.) Речник српскохрватскога књижевног језика IVI. Нови Сад: Матица српска, 1967-1976.

Havránek, B., J. Bělič, M. Helcl, A. Jedlička (eds.) Slovník spisovného jazyka českého I-IV. Praha: Československá akademie věd, 1960-1971. 
Hugo, Jan et al. Slovník nespisovné češtiny. Praha: Maxdorf, 2006.

Hujer, Oldřich et al. Příruční slovník jazyka českého I-IX. Praha: Státní pedagogické nakladatelství, 1935- 1957.

Imami, Petrit. Beogradski frajerski rečnik. Beograd: NNK International, 2000.

Lalević, Miodrag. Sinonimi i srodne reči srpskohrvatskoga jezika. Beograd: Nolit, 2004. Martincová, Olga, Vladimír Mejstř́k et al. Nová slova v češtině: slovník neologizmů. Praha: Academia, 1998.

Martincová, Olga, Vladimír Mejstř́ík et al. Nová slova v češtině: slovník neologizmů 2. Praha: Academia, 2004.

Svozilová, Nad’a, Hana Prouzová, Anna Jirsová. Slovník slovesných, substantivních a adjektivních vazeb a spojení. Praha: Academia, 2005.

\section{Katarina Mitrićević-Štepanek}

\section{THE RESEARCH OF VERBAL PREFIXES IN SERBIAN AND CZECH LANGUAGES WITH AN OVERVIEW OF OTHER SLAVONIC LANGUAGES}

\section{Summary}

The paper focuses on verbal prefixes as the subject of contrastive research in the Serbian and Czech languages with and provides a brief overview of research on this topic in Serbian and other Slavonic languages. The study gives a review of works dedicated to form and semantics as well as the functions of these language units and emphasizes their contribution to the contrastive and individual description of Slavonic languages and the completion of the picture of the system of verbal prefixes and their derivatives in these languages as a whole.

Keywords: verbal prefixes, verbal derivatives, contrastive analysis, Serbian language, Czech language, Slavonic languages. 